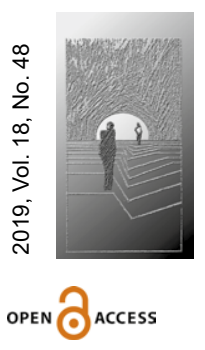

\title{
Rytuały rodzinne jako czynnik stałości i trwałości systemu rodzinnego w dynamicznie zmieniającym się świecie
}

\section{STRESZCZENIE}

CEL NAUKOWY: Celem artykułu jest przedstawienie zjawiska fenomenu rytuału rodzinnego w perspektywie jego funkcji oraz znaczenia dla życia rodziny i jej trwałości.

PROBLEM I METODY BADAWCZE: Prezentowany problem badawczy odnosi się do odpowiedzi na pytania: Czym są rytuały rodzinne? Jakie jest ich znaczenie dla życia rodzinnego i jego jakości w perspektywie stałości i trwałości? Zastosowano metodę analityczno-syntetyczną literatury przedmiotu.

PROCES WYWODU: Odwołując się do interdyscyplinarnych opracowań naukowych, dokonano analizy rytuału i rytuału rodzinnego z uwzględnieniem szerszej kategorii pojęciowej - tradycji. Wskazano też na fundamentalne funkcje celebrowania rytuału w rodzinie i korzyści, jakie można czerpać $z$ tych wydarzeń w wymiarze jednostkowym i rodzinnym.

WYNIKI ANALIZY NAUKOWEJ: Pielęgnowanie rytuałów rodzinnych (bez deformacji bogactwa i wymowy rytuału) przyczynia się do harmonijności i zintegrowania systemu rodzinnego, kształtowania podmiotowych relacji i bliskich więzi małżeńsko-rodzinnych, występowania elementów stałości, wierności i konsekwencji oraz reguł porządkujących funkcjonowanie rodziny. Rytuały rodzinne mogą zatem odgrywać rolę specyficznych niezmienników w zmiennym świecie oraz czynników więziotwórczych i integracyjnych rodziny.

WNIOSKI, INNOWACJE REKOMENDACJE: Cechą konstytutywną współczesności jest dynamiczna zmiana, która wpływa na życie człowieka, wywołując nowe zagrożenia i szanse. Wskazuje się na wzrastający rozpad rodziny oraz osłabienie relacji rodzinnych. W dobie wszechobecnej konsumpcji i cyfrowo-informacyjnej rewolucji rytuały rodzinne mogą stanowić swoiste remedium na zachowanie bliskich więzi w rodzinie, a przez to jej stałości i trwałości. Potrzebna jest w tym zakresie edukacja wszystkich pokoleń oraz promocja rytuałów rodzinnych i ich wartościowego celebrowania (działalność profilaktyczna), a także naukowa eksploracja tego pola problemowego.

$\rightarrow$ SŁOWA KLUCZOWE: RYTUAK, RYTUAŁ RODZINNY, RODZINA, TRADYCJA 


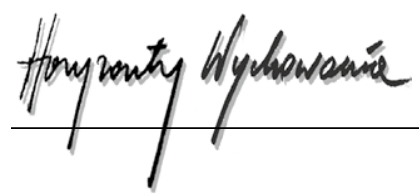

\begin{abstract}
Family Rituals as a Factor Determining Stability and Permanence of the Family System in the Dynamically Changing World
\end{abstract}

RESEARCH OBJECTIVE: The aim of the article is to present the phenomenon of a family ritual from the perspective of its function and significance for the quality of the life of a family and its permanence.

THE RESEARCH PROBLEM AND METHODS: The research problem focuses on finding answers to the following questions: What are family rituals? What is their significance for family life and its quality from the perspective of its stability and permanence? The study is conducted using the analytical and synthetic method of the analysis of subject literature.

THE PROCESS OF ARGUMENTATION: Referring to interdisciplinary scientific studies, the article presents the analysis of the ritual and family ritual, taking into account a broader conceptual category - tradition. It also indicates fundamental functions of celebrating rituals in the family and the benefits that can be derived from these events in both individual and family dimensions.

RESEARCH RESULTS: Adhering to family rituals contributes to the harmony and integration of the family system, shapes agentive relations and close marital and family ties, provides elements of stability, fidelity and consistency, as well as the rules organizing the functioning of the family. Family rituals may therefore play the role of specific constants in the changing world and serve as factors which bond and integrate the family.

CONCLUSIONS, INNOVATIONS, AND RECOMMENDATIONS: The constitutive feature of the modern world is a dynamic change that affects human life, causing new threats and offering opportunities. Family breakdown and the weakening of family relations are frequent phenomena. In the era of ubiquitous consumption and the digital-information revolution, family rituals may be seen as a kind of remedy helping to preserve close ties in the family, and thus its stability and permanence. What is needed in this respect is education of all generations and promotion of family rituals and their valuable celebration (preventive measures) as well as scientific exploration of this problem area.

$\rightarrow$ KEYWORDS: TRADITION, RITUAL, FAMILY RITUAL, FAMILY

\title{
1. Wprowadzenie
}

Fenomen rytuału rodzinnego ściśle wiąże się z kategorią tradycji. Stanowi ona fundament życia społecznego. Ukazuje pokoleniowość i trwanie rodziny w czasie pomimo dokonujących się globalnych dynamicznych zmian o różnym charakterze, które nie pozostają bez wpływu na życie małżeńsko-rodzinne, gdzie pojawiają się nowe szanse, ale i zagrożenia (np. wzrastająca liczba rozwodów i separacji, negatywne tendencje demograficzne, 
zanik rodziny wielopokoleniowej). Rytuały są zakorzenione w tradycji rodzinnej, która wyraża się w pielęgnowanych obrzędach, obyczajach i zwyczajach. Dlatego rodzina, będąc źródłem pierwszych i systematycznych życiowych doświadczeń człowieka, ma fundamentalny wkład w proces przekazu tradycji i jej podtrzymywania. Uwzględniając powyższe kwestie, celem artykułu uczyniono przedstawienie zjawiska fenomenu rytuału rodzinnego w perspektywie jego funkcji oraz znaczenia dla życia rodziny w kontekście jej stałości i trwałości. Zastosowano metodę analizy i syntezy literatury.

Tradycja jako kategoria pojęciowa jest obecna w refleksji w naukach humanistycznych i społecznych, ponieważ służy rozumieniu i wyjaśnianiu rzeczywistości, w której funkcjonuje człowiek. Pierwsze wnikliwe analizy tej kategorii zostały przeprowadzone przez E. Shilsa (za: Zagórska i Lipska, 2016, s. 212), który ujmował tradycję bardzo szeroko. Podkreślał, że jest ona tym, co spaja przeszłość i teraźniejszość, co stanowi wytwór działalności człowieka i co przekazuje się drogą transmisji międzygeneracyjnej, bo jest ważne dla danej grupy. Tradycja zatem to treści kultury obejmujące wierzenia i zwyczaje, sposoby myślenia, wzorce relacji społecznych, dobra materialne i naturalne. Na gruncie polskiej nauki J. Szacki (2011) wskazał na trzy sposoby klasyfikowania tego pojęcia: po pierwsze jako czynność w perspektywie transmisji społecznej, przekazywania treści kultury z pokolenia na pokolenie (przekaz dziedzictwa kulturowego); po drugie jako przedmiot, czyli to co jest przekazywane (pewne dziedzictwo społeczne materialne i niematerialne); po trzecie jako podmiot, czyli stosunek aktualnego pokolenia do przeszłości i do przekazu, jego akceptacja dziedziczenia lub odrzucenie.

Analiza kategorii tradycji rodziny wskazuje, że pielęgnowanie tradycji przez rodzinę sprzyja kształtowaniu tożsamości jej oraz członków, ponieważ kształtuje świat wartości rodziny i poszczególnych jednostek, wpływając na decyzje i motywy, postawy i zachowania. Tradycje rodziny często odnosi się do kultury rodziny, kultury środowiska rodzinnego ${ }^{1}$ czy kultury życia rodzinnego. Skutkiem tego jest szerokie ujęcie zjawiska, które obejmuje dziedzictwo materialne, historię rodziny, wiarę oraz praktyki religijne, wzorce relacji, kultywowane obyczaje, obrzędy i sposoby świętowania.

Istota tradycji rodzinnej, na co wskazują W. Zagórska i A. Lipska (2013; 2015), tkwi w sposobie jej przekazywania, który ma intuicyjny i nieintencjonalny charakter. Mamy tutaj do czynienia z przekazem międzypokoleniowym, ponieważ „wychodzi” ona od najstarszego i średniego pokolenia, które się z nią utożsamiają i przypisują jej dużą wartość („żywa tradycja rodzinna”), a celem przekazu jest pokolenie najmłodsze. Tradycja rodzinna dotyczy osób sobie bliskich, stanowi o ich tożsamości. W tej perspektywie może się pojawić refleksja, czy tradycja rodzinna nie traci aktualnie swojej mocy i wartości, ponieważ rodziny wielopokoleniowe odchodzą do lamusa, dominuje rodzina mała, dwupokoleniowa. Co więcej, wskazuje się na zwiększającą się przepaść kulturową między

${ }^{1}$ Kultura środowiska rodzinnego w pedagogice rodziny jest ujmowana w dwóch perspektywach: 1) kultura materialna rodziny (posiadanie domu jako przestrzeni życia rodziny, miejsce zabezpieczenia podstawowych potrzeb, co wiąże się z odpowiednim wyposażeniem domu oraz umiejętnościami zarządzania tą przestrzenią); 2) kultura niematerialna/duchowa rodziny (rodzina jako miejsce inkulturacji; elementy kultury duchowej to: słowo, symbol, rytuał, wartości) (Wilk, 2002). 


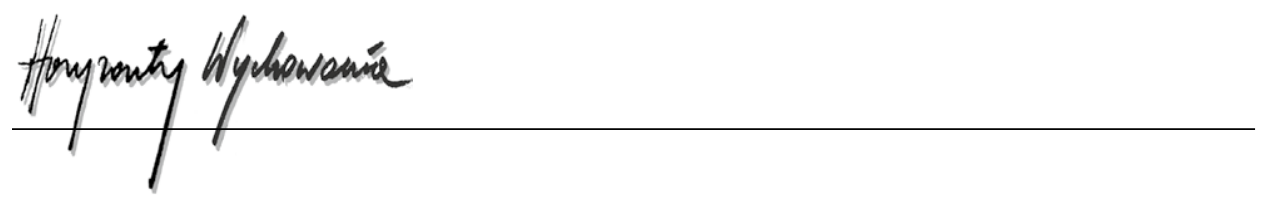

pokoleniami (kultura prefiguratywna) oraz coraz mniej cenione jest doświadczenie i mądrość życiowa seniorów.

\section{Istota rytuału rodzinnego}

Rytuały rodzinne², zakorzenione w tradycji rodziny, są częścią życia człowieka teraz, ale także były nią w przeszłości, ponieważ są to wydarzenia prastare, jak „rodowód ludzkich nadziei na sens życia, na lepszą przyszłość, na zwycięską moc życia” (Wilk, 2002, s. 73). W przeszłości, sięgając czasów kultur pierwotnych, rytuały miały zawsze charakter sakralny i były praktykowane wspólnotowo, a ich językiem był symbol, który otwiera na rzeczywistość wartości, znaczeń, stwarza przestrzeń do kontaktu z tym, co transcendentne.

„Termin «rytuał» pochodzi od łacińskiego słowa ritus i oznacza zarówno obrzęd, czy ceremonię religijną, jak i zwyczaj" (Zagórska i Lipska, 2015, s. 11). Obecnie rytuał jest definiowany jako

utrwalony tradycją, dokładnie określony i powtarzalny ciąg działań obrzędowych (w tym gestów, wypowiedzi itp.) mających znaczenie symboliczne - co oznacza, że działania te, dostępne ludzkim zmysłom w ich warstwie zewnętrznej, odsyłają do warstwy innej, niewypowiedzialnej, niewyrażalnej (Zagórska i Lipska, 2016, s. 215).

Inna definicja rytuału wskazuje, że

jest to zespół specyficznych dla danej kultury (zarówno w skali mikro, jak i makro) symbolicznych sekwencji określonych, sformalizowanych czynów i wypowiedzi, wykonywanych w celu osiągnięcia założonego efektu. Oczekiwany cel może być znacznie oderwany od efektu uzyskanego w wyniku działania. W dzisiejszym pojmowaniu rytuałów zalicza się do nich święta, rocznice, jak i wydarzenia okazjonalne czy codzienne, takie jak robienie zakupów, poranna kawa, bądź wyjazd na wakacje (Farnicka i Liberska, 2013, s. 220).

Ponadto autorzy wskazują na kluczowe elementy konstytutywne rytuału, do których zaliczono komponent praktyczny (służy organizowaniu zachowania grupowego) oraz komponent symboliczny (wzmacnia tożsamość i nadaje znaczenie zachowaniom oraz działaniom). Zatem można przyjąć, że rytuał rodzinny sprowadza się do zgodnego uczestnictwa członków rodziny w ważnych wydarzeniach, które mają na celu uhonorowanie i wzmocnienie rodzinnego poczucia wspólnoty (Zagórska i Lipska, 2015). Ważnymi czynnikami są tutaj powtarzalność, określone zachowania czy procedury związane z danym rytuałem oraz znaczenie, które wpisane jest w rytuał.

2 Jedna z pierwszych definicji rytuału rodzinnego została opracowana w 1950 r. przez J.H.S. Bossarda i E.S. Boll: „powtarzające się wydarzenia, których uczestnicy - członkowie rodziny mają ustalone zachowania oraz poczucie historycznej ciągłości i znaczenia wynikające z powtarzalności rytuału" (za: Zagórska i Lipska, 2016, s. 216). 
W. Zagórska i A. Lipska (2015), polskie badaczki rytuałów rodzinnych, wskazały, że zazwyczaj w życiu rodziny wyróżnia się trzy typy wydarzeń, które mogą się stać rytuałami. Są to: 1) zachowania rutynowe, 2) tradycje rodzinne i 3) uroczystości rodzinne. Różnią się one między sobą częstotliwością i złożonością. Zachowania rutynowe (1) występują w życiu codziennym rodziny, stąd są najczęstsze i nieplanowane, wymagają najmniejszego przygotowania, bo też są najprostsze. Do tego rodzaju zachowań zostały zaliczone powtarzające się każdego dnia czy tygodnia czynności związane z posiłkami, zasypianiem, spędzaniem czasu wolnego. Te zdarzenia mogą się stać rytuałami, gdy członkowie świadomie nadają im wyjątkowe znaczenie. Z kolei tradycje rodzinne (2), nazywane także obyczajami rodzinnymi, są bardziej złożone i wymagają pewnych przygotowań, odbywają się rzadziej - raz na rok lub kilka lat. Są charakterystyczne dla danej rodziny, ujawniają jej specyfikę i tożsamość. Danym wydarzeniom przypisywane są przez rodzinę określone wartości, przeżywane są one przez nią wyjątkowo, niepowtarzalnie, swoiście. Jako przykład tradycji rodzinnych można wskazać obchodzenie urodzin, imienin, rocznic czy wakacji rodzinnych przez konkretną rodzinę. Natomiast uroczystości rodzinne (3) obejmują zazwyczaj ciąg specyficznych zachowań, co wymaga stosownego przygotowania. Odbywają się one w życiu rodzinnym większości członków danej kultury. Pomimo różnic występujących między rodzinami ich zachowania towarzyszące uroczystościom są podobne. Głównie dotyczy to świąt religijnych (np. Bożego Narodzenia), które odbywają się raz do roku, oraz obrzędów przejścia, np. chrzest, ślub, pogrzeb, które odbywają się zwykle raz w życiu (Zagórska i Lipska, 2016; Zagórska i Lipska, 2015).

Eksplorując istotę rytuału rodzinnego, nie można pominąć obecnej w literaturze przedmiotu kwestii wymiarów struktury rytuału rodzinnego. Zjawisko to obejmuje następujące atrybuty: 1) częstość występowania rytuału w rodzinie, 2) role przypisane poszczególnym członkom rodziny oraz ich obowiązki związane z rytuałem, 3) regularność występowania rytuału, 4) obecność członków rodziny podczas rytuału, 5) emocje - zaangażowanie emocjonalne związane z rytuałem, 6) znaczenie symboliczne, 7) tradycja - przekaz rytuału z pokolenia na pokolenie, 8) przygotowania - czynności dotyczące planowania i przygotowań związanych z rytuałem (za: Zagórska i Lipska, 2015).

Powyższe analizy wskazują, że rytuał rodziny może dotyczyć różnych sfer jej funkcjonowania. I tak, może się odnosić do zwyczajów domowych, gdzie członkowie rodziny pielęgnują doroczne święta (np. religijne - Wielkanoc), uroczystości okolicznościowe (np. świętowanie rocznic - urodziny). Wówczas rytuały służą kultywowaniu zwyczajów i obyczajów, które zwykle są przekazywane z pokolenia na pokolenie (sankcja kulturowa, ciągłość historyczna) poprzez różnego rodzaju środki, tj. gesty i wypowiedzi, rekwizyty i dekoracje, specjalne stroje, określone czynności przygotowawcze i obrzędy właściwe oraz świąteczne potrawy. Ponadto w rodzinach mogą występować i być podtrzymywane tylko pewne elementy określonych zachowań i działań, czy wydarzenia okazjonalne, które określa się mianem codziennych rytuałów (rytuałów dnia codziennego). Te zdarzenia mają dla członków rodziny subiektywne znaczenie i symboliczny wymiar. 


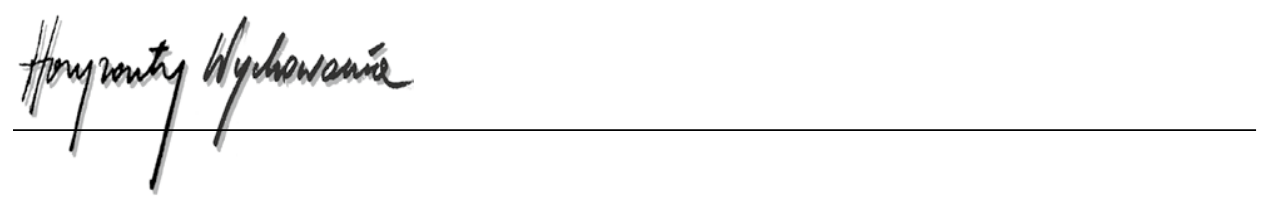

\section{Funkcje rytuałów rodzinnych}

Autorzy ${ }^{3}$ podejmujący badania nad rytuałami wskazują na różne znaczenia i funkcje, które są im przypisywane, zarówno w wymiarze jednostkowym, jak i grupowym, społecznym. Przede wszystkim podkreśla się funkcję społeczną, powiązaną z funkcją komunikacyjną i regulacyjną oraz więziotwórczą i integracyjną, ale także kulturową i przystosowawczą, ponieważ rytuały gromadzą zbiorowość na celebracji, przenoszą w inny odświętny wymiar, kiedy człowiek zwraca się do siebie samego (uświadomienie sobie własnych przeżyć), do ludzi (by wspólnie z nimi być, bawić się, rozmawiać, przeżywać, a nie załatwiać interesy), do Boga (poprzez modlitwę, kontemplację, rozmyślanie) (Braun-Gałkowska, 2008). Te zjawiska sprzyjają przeżyciu wspólnoty, wzmocnieniu przynależności, budowaniu więzi i ładu społecznego oraz przywracaniu harmonii, poczucia stabilizacji i bezpieczeństwa ze względu na element stałości i powtarzalności.

Rytuałom rodzinnym przypisuje się także funkcje wychowawcze i socjalizacyjne oraz terapeutyczne. Wynika to z faktu, że rytuały umożliwiają wyrażanie i przeżywanie emocji, doprowadzają do zmiany, ale i pozwalają zapanować nad zmiennością, bo niektóre praktyki wyrażają symboliczne panowanie nad czasem i przestrzenią, zmniejszając strach i nieuchronność, ułatwiając jej zaakceptowanie. Kształtują tożsamość osoby i społeczności, poświadczają i wzmacniają więzi społeczne dzięki spotkaniom oraz poczucie przynależności poprzez element emocjonalnego zaangażowania. Dzięki nim można przekazywać wartości z pokolenia na pokolenie, obcować z sacrum, tajemnicą czy też ideałami. Opierają się bowiem na tym, co trwałe, niezmienne i wartościowe (Maisonneuve, 1995; Eliade, 1997).

Podtrzymywanie tradycji i pielęgnowanie rytuałów w rodzinie (co wiąże się z ich przygotowaniem, zaangażowaniem, celebrowaniem i przeżywaniem) jest fundamentalne, ponieważ w tych formach obecne są najważniejsze w życiu wartości, świadczą one o zintegrowaniu rodziny oraz bliskich relacjach. Mają również znaczenie wychowawcze, gdyż sprzyjają kształtowaniu właściwej atmosfery w rodzinie, przyczyniając się do poczucia bezpieczeństwa i stabilizacji, wyznaczania stosownych granic i zasad obowiązujących w rodzinie. Rytuały wskazują na określone wzorce do naśladowania najmłodszemu pokoleniu, ponadto pomagają zrozumieć, kim się jest i jakie jest swoje miejsce w świecie oraz zakorzeniają i dają poczucie przynależności. Uczą przeżywania i wyrażania emocji, wzruszenia, umacniają więzi rodzinne i zbliżają członków rodziny do siebie, dają szansę na bycie ze sobą w bezpośrednim kontakcie i uczą podmiotowego traktowania siebie nawzajem. Dzisiaj w pędzie życia są to cenne chwile bycia ze sobą, gdy poświęcamy sobie uwagę i czas, możemy ze sobą porozmawiać i wysłuchać siebie.

Domowe obyczaje: codzienne i świąteczne, stanowią wsparcie dla dokonującego się w codzienności rodzinnej wychowania (Błasiak i Chmura, 2017), gdzie są obecne

${ }^{3}$ Polskie badania nad rytuałami realizowali: m.in. A. Zadrożyńska, B. Ogrodowska, M. Farnicka, H. Liberska, W. Zagórska i A. Lipska, E. Dryll, A. Cierpka, A. Pankalla, A. Węgrzyniak, T. Stępień, J. Komorowska, J. Szacki. 
określone doświadczenia i przeżycia. Pielęgnowanie obyczajów sprzyja temu, co łączy i buduje wspólnotę oraz wpływa na postawy członków rodziny, wskazuje bowiem na wartości akceptowane i realizowane w rodzinie. Szczególnym przykładem codziennego obyczaju może być wspólny posiłek, spotkanie przy stole każdego dnia, co dzisiaj tak łatwo lekceważymy. Obyczaj świąteczny natomiast odnosi się do czasu wolnego, odpoczynku, celebrowania rocznic i świąt o różnym charakterze. Wówczas jest więcej możliwości okazywania sobie sympatii i życzliwości poprzez słowa, gesty, niespodzianki i prezenty, które są wyrazem pamięci, troski i życzliwości (Błasiak i Chmura, 2017).

Jak zostało to już podkreślone, rytuały mają wpływ na kształtowanie tożsamości zarówno zbiorowej, jak i jednostkowej, tworzą ramy dla rozwoju. Mają także znaczenie dla procesu nabywania autonomii i separacji od rodziny pochodzenia dla młodych ludzi, a z kolei w późniejszym okresie mogą się stać stałymi elementami, które pozwalają na zachowanie więzi z rodziną pochodzenia (np. świętowanie imienin, urodzin), bo są okazją do rodzinnych spotkań. Rytualizacja życia rodzinnego wiąże się także z procesem adaptowania się młodych rodziców do roli opiekunów dziecka (Zagórska i Lipska, 2015; Zagórska i Lipska, 2013).

W literaturze psychologicznej podkreśla się także funkcję terapeutyczną rytuałów rodzinnych. Wielu klinicystów wprowadza do terapii rodzin rytuały jako jej istotny element. Badacze wykazują także, że zachowanie w rodzinie rytuałów, mimo istniejących w niej problemów, pełni funkcję ochronną w stosunku do dzieci. Ponadto naukowe eksploracje podkreślają związek między codziennymi zwyczajami i rytuałami a zdrowiem psychicznym członków rodziny oraz ich dobrostanem. Siła rytuału w kontekście terapeutycznym wynika z możliwości integrowania rodziny przez celebrowany rytuał, wzmacnianie jej spójności, przywracanie porządku, stwarzanie okazji do przekazu wartości, wyrażanie w sposób symboliczny treści trudnych (Zagórska i Lipska, 2015).

Kompleksowe ujęcie funkcji, które spełniają rytuały rodzinne, przedstawiły w swoich opracowaniach W. Zagórska i A. Lipska (2015, s. 122). Za J. Friesenem autorki wskazały na sześć funkcji: 1) oznaczenie zmiany w bieżącej strukturze społecznej, ponieważ rytuały symbolizują zmianę i ułatwiają jej akceptację m.in. poprzez obecność innych członków rodziny; 2) ułatwienie przekazywania wartości i przekonań; 3) wspieranie w procesie kształtowania tożsamości rodzinnej poprzez poczucie ciągłości i zakorzenienie oraz zwracanie uwagi na przyszłą perspektywę; 4) wspieranie w trudnych chwilach pełnych silnych emocji; 5) ułatwienie współpracy między jednostkami, rodzinami i społecznościami; 6) uzdrawianie, wsparcie dawane sobie w sytuacjach trudnych, w sytuacjach straty, rytuały ułatwiają poradzenie sobie $z$ nimi.

Powyższe wskazania sugerują, że należy uznać, iż rytuały rodzinne to wydarzenia pozytywne, ponieważ scalają rodzinę i dają poczucie wspólnoty oraz przynależności do grupy, wzmacniają jej tożsamość. Ponadto sprzyjają osobistemu rozwojowi i budowaniu własnych kompetencji społecznych wykorzystywanych poza środowiskiem rodzinnym, przez co umacnia się indywidualne poczucie tożsamości. 


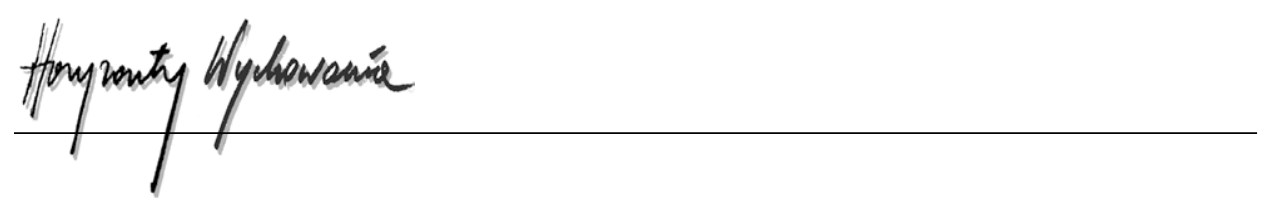

\title{
4. Zakończenie
}

Reasumując przedstawione w artykule pola problemowe, należy stwierdzić, iż rytuał rodzinny można interpretować w kategoriach stałości życia rodzinnego i poczucia bezpieczeństwa, ponieważ zawiera w sobie czynnik wartości i zasad, które wynikają i wiążą się z cyklem życia człowieka i rodziny, z systemem prawnym i religijnym. Ponadto przyczyniają się do tego, że osoba była i jest „społecznie usankcjonowana i zatwierdzona” (Tymochowicz, 2013/2014, s. 189). Uroczystości rodzinne sprawiają, że zacieśniają się relacje i więzi, członkowie rodziny świadczą sobie pomoc na różnych płaszczyznach, okazują szacunek i życzliwość. Ich powtarzalność sprzyja temu, że stają się swoistymi niezmiennikami w dynamicznie zmieniającym się życiu człowieka, jak i w świecie zewnętrznym.

Ważną kwestią jest to, że rytuały opierają się na tym, co wartościowe, trwałe i niezmienne, a przez to sprawiają, że świat jest bardziej przewidywalny i bezpieczny, a sam człowiek doświadcza wewnętrznego pokoju, harmonii i pogody ducha. Rytuały strzegą tożsamości rodziny oraz tożsamości człowieka, dają poczucie sensu. Ułatwiają też odprężenie, zmniejszają codzienny stres, przywracają radość i dobre samopoczucie (Zagórska i Lipska, 2016).

Trzeba też zaznaczyć, że rytuały ewoluują i przekształcają się ze względu na ich adaptacyjną funkcję. To naturalny proces. Wówczas zmieniają one swoją formę w zależności od sytuacji życiowej oraz wpływu czynników socjokulturowych i historycznych. Istotne zmiany związane z praktykowaniem rytuałów dotyczą

\begin{abstract}
przeniesienia praktyk rytualnych z obszaru sacrum na obszar świecki (nawet rytuał religijny, taki jak Boże Narodzenie, „przeniósł się do domu” - ma niejednokrotnie charakter bardziej rodzinny niż religijny) oraz przesunięcia praktyk rytualnych z dużych grup do małych (ze społeczeństwa do rodziny). Również znaczące są zmiany związane z samą rodziną, jak na przykład „zindywidualizowany charakter” współczesnej rodziny, który pozwala na unikatowe interpretowanie i przeżywanie tego, co jest uznawane za rytuał, oraz „zamknięcie rodziny", czyli mniejszy nacisk na gromadzenie się w szerszym niż najbliższa rodzina gronie (Zagórska i Lipska, 2015, s. 20).
\end{abstract}

Każda rodzina tworzy specyficzne warunki do świętowania, ponadto istnieją różnice w sposobie praktykowania rytuałów. Rodziny w różnym stopniu kładą nacisk na obecność i celebrowanie rytuałów w ich środowisku życia. Może to wynikać ze stylu życia rodziny, odmiennych temperamentów członków rodziny oraz ich potrzeby ekspresji. W rezultacie rodziny różnią się między sobą liczbą pielęgnowanych tradycji, jak i ich jakością, czyli tym, jaki wymiar rytuału jest dla nich najważniejszy. Mimo tych różnic wydaje się, że ze względu na funkcje, które pełni rytuał, wszystkie rodziny tych rytuałów potrzebują.

Współczesna rodzina asymiluje nowoczesne zjawiska, ulegając wyraźnej transformacji w zakresie struktury, celów i świadomości rodzinnej. Zjawiska te w jednych rodzinach mogą optymalizować jej funkcjonowanie, w innych mogą wywołać zagubienie i chaos, a przez to stanowić zagrożenie rozpadu. W obszarze wspierania rodziny potrzebne są 
działania edukacyjne wszystkich pokoleń prowadzące do akceptacji zmiany świata zewnętrznego (zmiana jest nieuchronnym procesem) przy zachowaniu stałości i trwałości świata rodzinnego. Fundamentem tej stałości może być tradycja i rodzinne rytuały, które sprzyjają poczuciu bezpieczeństwa i stabilności, jedności i wspólnotowości, obniżają lęki, działają więziotwórczo i integracyjnie, podtrzymują wzajemne kontakty, przekazują wartości i przekonania. Przy czym warto też podkreślić, że pielęgnowanie tradycji i rytuałów rodzinnych będzie dokonywało się w rodzinach, gdy ich członkowie będą przekonani o ich wartości i dobrodziejstwie dla nich samych i systemu rodzinnego. Dzisiaj na skutek szybkiego tempa życia, ciągłego braku czasu, człowiek często gubi to, co najważniejsze dla jego egzystencji i człowieczeństwa. Dotyczy to też rytuałów rodzinnych, gdy dochodzi do deformacji, zawężania i zubożenia bogactwa i ich treści, co prowadzi do dehumanizacji życia. Stąd refleksja nad znaczeniem rytuałów i obrzędów w życiu rodzinnym, ale także ich treścią i symbolicznym znaczeniem, wydaje się ważna i aktualna.

\section{BIBLIOGRAFIA}

Błasiak, A. i Chmura, A. (2017). Codzienność życia rodziny jako przestrzeń wychowania. Wybrane teoretyczne aspekty. W: A. Walulik i J. Mółka (red.), Septuaginta pedagogiczno-katechetyczna. Kraków: Akademia Ignatianum w Krakowie.

Braun-Gałkowska, M. (2008). Psychologia domowa. Lublin: Wydawnictwo KUL.

De Saint-Exupery, A. (1993). Mały Książę. Warszawa: Instytut Wydawniczy PAX.

Eliade, M. (1997). Inicjacja, obrzędy, stowarzyszenia tajemne. Kraków: Znak.

Farnicka, M. i Liberska, H. (2013). Wizja własnego życia i rytuały rodzinne wskazywane jako życiowe źródła wsparcia. Rocznik Lubuski, t. 39, cz. 2, 215-225.

Maisonneuve, J. (1995). Rytuały dawne i współczesne. Gdańsk: GWP.

Szacki, J. (2011). Tradycja. Warszawa: Wydawnictwo Uniwersytetu Warszawskiego.

Tymochowicz, M. (2013/2014). Rola tradycyjnych obrzędów przejścia w podtrzymywaniu więzi rodzinnych i społecznych (na przykładach z obszaru woj. lubelskiego). Rocznik Lubelskiego Towarzystwa Genealogicznego, t. V, 188-211.

Wilk, J. (2002). Pedagogika rodziny. Lublin: Wydawnictwo Poligrafia Salezjańska.

Zagórska, W. i Lipska, A. (2013). „Tak kiedyś zostało ustalone”. Rytuały rodzinne z perspektywy autobiograficznej młodych dorosłych. Psychologia Wychowawcza, 4, 117-137.

Zagórska, W. i Lipska, A. (2015). Rytuały rodzinne - koncepcje, badania, funkcje psychologiczne. Psychologia Rozwojowa, t. 20, nr 2, 11-25.

Zagórska, W. i Lipska, A. (2016). Pokochać tradycję i rytuały rodzinne. Fides Et Ratio, 211-223.

Copyright and License

This article is published under the terms of the Creative Commons Attribution - NoDerivs (CC BY- ND 4.0) License http://creativecommons.org/licenses/by-nd/4.0/ 